\title{
Persepsi Member As Gym Fitness Center Terhadap Strategi Komunikasi Pemasaran
}

\author{
Puput Sekar Sari ${ }^{1}$, Maliah $^{2}$ \\ ${ }^{1}$ FKIP Universitas PGRI Palembang, sari puput88@univpgripalembang.ac.id, \\ ${ }^{2}$ Fakultas Ekonomi dan Bisnis Universitas PGRI Palembang, maliah@univpgri-palembang.ac.id
}

\begin{abstract}
ABSTRAK
Tujuan dalam penelitian ini adalah Untuk mengetahui Persepsi Member AS Gym Fitness Center Terhadap Strategi Komunikasi Pemasaran yang terdiri dari faktor advertising, personal selling dan sales promotion. Metode penelitian ini adalah penelitian deskriptif dengan menggunakan metode survei berupa angket. Populasi dalam penelitian adalah seluruh member AS Gym fitness Center berjumlah 76 member. Dalam penelitian ini sampel yang diambil menggunakan teknik Accidental sampling dengan jumlah 37 responden. Uji validitas instrumen menggunakan korelasi product moment dengan hasil dari 20 butir soal dinyatakan valid dengan nilai korelasi sebagai berikut

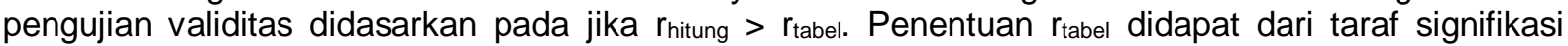
$0,05 \%$ dengan $\mathrm{DF}=\mathrm{N}-1(20-1)$ yaitu 19 . Maka rtabel diperoleh 0,433. Uji Reliabilitas Instrumen menggunakan rumus Alpha Cronbach dengan nilai interprestasi koefisien reliabilitas tinggi yaitu antara 0.60 - 0.799. Pengumpulan data menggunakan observasi, dokumentasi dan kuisioner. Analisis data menggunakan deskripsi persentase. Teknik analisis data menggunakan analisis deskriptif yang dituangkan dalam bentuk persentase. Berdasarkan analisis data dan temuan hasil penelitian, maka dapat disimpulkan bahwa strategi komunikasi pemasaran yang dilakukan oleh pengusaha AS Gym Fitness Center Palembang ditinjau dari faktor advertising adalah $30 \%$ disukai member, dari faktor personal selling adalah $36 \%$ disukai member dan dari faktor sales promotion sebesar $34 \%$ disukai member.
\end{abstract}

Kata Kunci: Persepsi, Komunikasi Pemasaran, Fitness Center

\section{ABSTRACT}

The purpose of this study was to determine the perceptions of AS Gym Fitness Center members on marketing communication strategies consisting of advertising, personal selling and sales promotion factors. This research method is descriptive research using a survey method in the form of a questionnaire. The population in the study were all members of the AS Gym fitness Center totaling 76 members. In this study, samples were taken using accidental sampling technique with a total of 37 respondents. Test the validity of the instrument using the product moment correlation with the results of 20 items being declared valid with the following correlation value. The validity test is based on if rcount > rtable. The determination of the rtable was obtained from a significance level of $0.05 \%$ with $D F=N-1$ (20-1) which is 19. Then the rtable was obtained 0.433. The instrument reliability test uses the Cronbach Alpha formula with a high reliability coefficient interpretation value, which is between 0.60 - 0.799. Collecting data using observation, documentation and questionnaires. Data analysis used percentage description. The data analysis technique used descriptive analysis as outlined in the form of a percentage. Based on data analysis and research findings, it can be concluded that the marketing communication strategy carried out by US Gym Fitness Center Palembang entrepreneurs in terms of advertising factors is 30\% preferred by members, from personal selling factors is $36 \%$ preferred by members and from sales promotion factors is $34 \%$ liked by members.

Keywords: Perception, Marketing Communication, Fitness Center

\section{A. PENDAHULUAN}

Seiring bertambahnya usia dan meningkatnya aktivitas yang dijalani seseorang, semakin menurun pula tingkat kesadaran seseorang akan pentingnya berolahraga sebagai kebutuhan sehari-hari untuk menjaga kebugaran tubuh. Kebugaran tubuh manusia tidak dapat muncul secara spontan, karena itu, olahraga sebagai aktivitas 
fisik yang menjadi sarana untuk membina dan mempertahankan sehingga tetap bugar mutlak dilakukan dengan melibatkan komponen kesegaran jasmani dengan metode latihan yang benar secara terarah dan terukur. Hal tersebut sejalan dengan yang diamanatkan dalam Undang-Undang Sistem Keolahragaan Nasional Nomor 3 Tahun 2005 bahwa, "olahraga adalah segala kegiatan yang sistematis untuk mendorong, membina, serta mengembangkan potensi jasmani, rohani, dan sosial". Sedangkan menurut Colledge. F. et al (2020) "Physical exercise is an important element of healthy human life. However, exercise can also have unhealthy consequences when engaged in excessively and without proper recovery".

Menurut Giriwijoyo (2004:36): "pusat kebugaran adalah suatu kegiatan dalam ruangan dengan menawarkan kegiatan olahraga dari yang tanpa menggunakan alat, sampai yang menggunakan alat-alat yang mahal dan canggih, yang diantaranya bertujuan prestasi." Dengan berolahraga fitness (kebugaran) terjadi kerjasama berbagai otot tubuh yang ditandai dengan perubahan kekuatan otot, kelenturan otot, kecepatan reaksi, ketangkasan, koordinasi gerakan dan daya tahan (endurance) sistim kardiorespirasi. Nursan (2019). Dengan tingkat kebugaran jasmani yang tinggi akan dimaknai sebagai kemampuan tubuh dari seseorang untuk melakukan tugas pekerjaan sehari-hari tanpa menimbulkan kelelahan yang berarti. Seiring dengan banyaknya masyarakat yang ingin meningkatkan physical fitness (kebugaran jasmani), sehingga tidak ketinggalan pula para pengusaha membuat Pusat Kebugaran Jasmani (fitness centre) dengan cara memfasilitasi pengadaan prasarana, sarana, dana dan SDM menjadi lebih baik dan menarik.

Fitness center sebagai tempat olahraga mempunyai banyak keunggulan dibanding dengan tempat olahraga yang lain, contohnya ada instruktur yang mengawasi latihan, dapat dilakukan secara individu dan dapat dilakukan kapan saja tidak mengenal waktu. Terbatasnya instruktur yang professional dengan kompetensi pengelolaan fitness dan strategi pemasaran yang tidak berjalan dengan baik terkadang membuat program-program yang ditawarkan di fitness center tidak bisa berjalan sesuai promosi yang ditawarkan. Sebagaimana halnya di Kota Palembang pusat kebugaran jasmani sudah menjamur, tiap kecamatan terdapat fitness center.

DAFTAR FITNESS CENTER TIAP KECAMATAN DI KOTA PALEMBANG

\begin{tabular}{|c|l|l|}
\hline NO & \multicolumn{1}{|c|}{ KECAMATAN } & \multicolumn{1}{c|}{ NAMA FITNESS CENTER } \\
\hline 1 & Alang-Alang Lebar & Gisuk Fitness Center, Joker Gym \\
\hline 2 & Bukit Kecil & Life Style Fitness, BFIT \\
\hline 3 & Gandus & Sanggar Senam Azzah \\
\hline 4 & llir Barat I & Graha Gym,Celebrity Fitness (PI) \\
\hline 5 & Ilir Barat II & Project Gym \& Aerobic, Ten Gym \\
\hline 6 & llir Timur I & Jetset Fitness, Boss Fitness \\
\hline 7 & llir Timur II & Dj Fitness center, Bangau Fitness \\
\hline 8 & Ilir Timur III & Pusat Diet Palembang \\
\hline 9 & Jakabaring & Jakabaring Fitness \\
\hline 10 & Kalidoni & Pusri Fitness center, Power Gym \\
\hline 11 & Kemuning & Centrall Fitness, Ekspresso, Body Fit \\
\hline 12 & Kertapati & Sanggar Sherine \\
\hline 13 & Plaju & Fitness Center RU III, HSE Fitness \\
\hline 14 & Sako & Klub Sehat Bahagia, Titan Gym \\
\hline 15 & Seberang Ulu I & RZ Fitnees \& Aerobic, Kyoso Gym \\
\hline 16 & Seberang Ulu II & Lembah Fitness Center, Svastha \\
\hline 17 & Sematang Borang & AW Gym \\
\hline 18 & Sukarami & AS Gym, Hoge Gym,Perfecto \\
\hline
\end{tabular}

Sumber : Wongkitogalo.Blogspot.com 
Komunikasi pemasaran (marketing Communication) adalah usaha yang dilakukan untuk menginformasikan, membujuk, mengingatkan atau menyampaikan kepada publik (konsumen) mengenai keberadaan produk maupun jasa yang dijual dan beredar di pasar agar dikenal, dibeli kemudian menjadi pelanggan. Komunikasi pemasaran memegang peranan sangat penting bagi pemasar. Tanpa komunikasi, konsumen maupun masyarakat secara keseluruhan tidak akan mengetahui keberadaan produk di pasar. Hal ini senada dengan pendapat Pedersen, et al, (dalam Reftari.D.H.dkk :2018) mengungkapkan "Kegiatan pemasaran wajib dimiliki oleh setiap perusahaan maupun organisasi agar dapat terus berkembang, dalam hal ini komunikasi olahraga melibatkan proses diantaranya olahraga komunikasi, dan komunikasi antara praktisi industri olahraga, organisasi, dan para pemangku kepentingan internal dan eksternal untuk mendapatkan hubungan timbal balik antara mereka". Penentuan siapa saja yang menjadi sasaran komunikasi sangat menentukan keberhasilan komunikasi. Dengan penentuan sasaran yang tepat, proses komunikasi akan berjalan efektif dan efisien (Sutisna, 2012:268). Komunikasi pemasaran terdiri dari 2 (dua) elemen penting, yaitu komunikasi dan pemasaran. Secara umum, komunikasi adalah proses penyampaian pesan yang dilakukan oleh komunikator atau pengirim pesan kepada komunikan atau penerima pesan melalui saluran tertentu untuk mempengaruhi sisi kognitif, afektif, dan psikomotor penerima pesan.

Pemasaran disini merupakan sebuah proses dimana ketika mereka ingin mendapatkan sesuatu untuk meningkatkan institusi atau instansi mereka tentunya mereka harus melewati sebuah proses sosial yang harus dilewati untuk menciptakan sebuah branding atau penempatan sosial. Strategi pemasaran itu tidak hanya untuk mengenalkan sebuah produk atau branding saja melainkan juga untuk mengedukasi para konsumen tentang apa produk yang mereka tawarkan atau jasa apa yang mereka tawarkan sehingga muncul di benak mereka keinginan untuk membeli produk atau jasa yang

Dengan bauran pemasaran, yaitu kiat kelompok pemasaran yang digunakan untuk mencapai sasaran pemasarannya dalam pasar sasaran. Jika olahraga dikelola secara profesional dapat mendatangkan keuntungan ekonomi disamping keuntungan non ekonomi (Sukarmin, 2014).

UU Republik Indonesia nomor 3 tahun 2005 tentang sistem keolahragaan nasional, pasal 97 poin (2) menyebutkan bahwa Industri olahraga dapat berbentuk jasa penjualan kegiatan cabang olahraga sebagai produk utama yang dikemas secara profesional yang meliputi; kejuaraan nasional dan internasional, pekan olahraga daerah wilayah, nasional, dan internasional; promosi, eksibisi, dan festival olahraga atau kagenan, layanan informasi, dan konsultasi keolahragaan.

Pusat Kebugaran (Fitness Center) adalah industri olahraga yang menggiurkan. Kasus yang unik dinilai dari usaha yang bergerak dibidang olahraga yang memiliki strategi promosi yang berbeda dengan industri olahraga lainnya, dilihat dari salah satu strateginya melalui event body contes dan senam aerobic sebagai salah satu cara untuk mempromosikan pusat kebugaran/ fitness center melalui event tersebut. Dimana pertandingan atau event olahraga yang ada di Indonesia, tidak ditemukan strategi promosi yang serupa dari cabang-cabang olahraga lainnya. 


\section{B. KAJIAN TEORI \\ Persepsi}

Persepsi merupakan kesan yang diperoleh oleh individu melalui panca indera kemudian dianalisa (diorganisir), diintepretasi dan kemudian dievaluasi, sehingga individu tersebut memperoleh makna. Persepsi pada hakikatnya adalah proses kognitif yang dialami oleh setiap orang dalam memahami informasi tentang lingkungannya, merupakan suatu penafsiran yang unik terhadap situasi. Oktradiksa (dalam Sari, F.K. dkk). Sedangkan menurut Fadila \& Lestari (2013) persepsi adalah segala proses pemilihan, pengorganisasian dan penginterprestasian masukan informasi, sensasi yang diterima melalui penglihatan, perasaan, pendengaran, penciuman dan sentuhan untuk menghasilkan makna.

Proses timbulnya persepsi dimulai dari penangkapan indera seseorang terhadap peristiwa, kejadian atau sesuatu yang ada di alam, kemudian di proses di dalam otak, proses tersebut menghasilkan belajar dimulai dengan adanya persepsi. Dalam strategi komunikasi pemasaran persepsi yang dibentuk oleh seseorang diterima berdasarkan strategi dari penyedia jasa atau produk.

\section{Hakikat Pemasaran}

Definisi pemasaran atau marketing adalah kegiatan yang dilakukan oleh perusahaan untuk mempromosikan suatu produk atau layanan yang mereka punya. Menurut Kotler (dalam Sukarmin 2014:59) yang dimaksud dengan pemasaran adalah proses perencanaan dan pelaksanaan dari perwujudan, pemberian harga, promosi dan distribusi dari barang/jasa dan gagasan untuk menciptakan pertukaran dengan kelompok sasaran yang memenuhi tujuan pelanggan dan organisasi. Lebih lanjut dikatakan bahwa dalam pemasaran perlu ada manajemen pemasaran, yaitu suatu proses yang mencakup analisis, perencanaan, pelaksanaan, dan pengawasan yang meliputi barang atau jasa serta gagasan berdasarkan pertukaran dan tujuannya dengan memberikan kepuasan bagi para pihak yang terlibat. Dengan demikian, manajemen pemasaran olahraga dapat diartikan sebagai suatu proses analisis perencanaan, pelaksanaan, dan pengendalian tentang produk/jasa, harga, promosi, distribusi/penyampaian, fasilitas fisik, orang, proses, dan janji yang diberikan untuk memenuhi kebutuhan individu atau organisasi. Pemasaran selalu menjadi ujung tombak institusi atau sebuah badan usaha baik yang berskala besar mauapun yang bersekala kecil untuk berhasil dalam kegiatan usahanya. Semakin cepat dalam proses pemasaran, maka usaha yang di lakukan oleh badan usaha tersebut akan semakin lancar.

\section{Komunikasi Pemasaran}

Komunikasi pemasaran adalah kegiatan pemasaran dengan memanfaatkan teknik-teknik komunikasi yang ditujukan untuk memberikan informasi bagi orang banyak dengan harapan tercapainya tujuan perusahaan yakni peningkatan pendapatan (laba). Sutisna, 2012 mengemukakan bahwa komunikasi pemasaran merupakan usaha untuk meyampaikan pesan kepada publik terutama konsumen saran mengenai perbedaaan produk di pasar. Kegiatan komunikasi pemasaran merupakan rangkaian kegiatan untuk mewujudkan suatu produk, jasa, ide, dengan menggunakan bauran pemasaran (marketing mix) yaitu iklan (advertising), penjualan tatap muka (personal selling), promosi penjualan (sales promotion), hubungan masyarakat dan publisitas (public relation and publicity) serta pemasaran langsung (direct marketing). Purba.dkk. (2006:126-127). 


\section{Pusat Kebugaran ( Fitness Center )}

Dalam Bahasa Inggris fitness center berasal dari kata fitness dan center, yang dalam Bahasa Indonesia fitness artinya kebugaran dan center artinya pusat, jadi fitness center adalah pusat kebugaran. Menurut Giriwijoyo (dalam Djoko Pekik, 2000) pusat kebugaran adalah suatu kegiatan dalam ruangan dengan menawarkan kegiatan olahraga dari yang tanpa menggunakan alat, sampai yang menggunakan alat-alat yang mahal dan canggih, yang diantaranya bertujuan prestasi."

Dikarenakan usaha ini bergerak di bidang jasa, maka para pelaku usaha ini pasti bersaing dalam menarik pelanggan sebanyak-banyaknya dan berupaya untuk meningkatkan kepuasan pelanggannya, hal ini dilakukan dengan cara menawarkan pelayanan yang bervariasi diantaranya penyediaan sarana dan prasarana yang lengkap dan nyaman hingga penyediaan jasa personal trainer atau instruktur. Upayaupaya yang telah disebutkan sebelumnya dilakukan oleh pengelola merupakan salah satu cara untuk menciptakan kepuasan pelanggan sehingga pelanggan dapat tertarik menggunakan fasilitas yang disediakan oleh pengelola. Awalnya olahraga fitness dikenal sebagai olahraga angkat besi atau olahraga binaraga yang pada saat itu olahraga ini identik dengan orang-orang yang bertubuh besar dengan massa otot yang besar dan kuat, tetapi seiring dengan perkembangan zaman dan berubahnya kebutuhan di masyarakat terhadap olahraga ini, sehingga ada perubahan persepsi masyarakat tentang olahraga fitness, yaitu anggapan bahwa olahraga fitness hanya bertujuan untuk membentuk tubuh menjadi besar dan berotot saja, melainkan sudah banyak anggota masyarakat yang menganggap bahwa olahraga fitness adalah salah satu olahraga yang dapat dijadikan sebagai gaya hidup sehat. Jadi secara tidak langsung olahraga ini pun telah merubah kebiasaan atau pola hidup masyarakat menjadi pola hidup sehat dengan olahraga.

\section{Member / Anggota}

Member adalah kata yang berasal dari bahasa asing, tepatnya Bahasa Inggris. Kata ini bermakna anggota. Anggota merupakan sebuah status yang diberikan kepada seseorang atau lembaga dari sebuah perkumpulan, organisasi, atau institusi setelah memenuhi beberapa persyaratan yang telah ditetapkan oleh perkumpulan, organisasi, atau institusi tersebut. Menurut Gronroos (2000:23) member merupakan suatu pengakuan sebagai pelanggan yang bergabung dalam suatu organisasi, perusahaan atau kelompok secara resmi dan diakui.

\section{METODE PENELITIAN Populasi dan Sampel}

Penelitian ini adalah penelitian deskriptif dengan menggunakan metode survei berupa angket. Menurut Suharsimi Arikanto (2013:174) metode deskriptif adalah: "Penelitian yang dimaksudkan untuk menyelidiki keadaan, kondisi atau hal lain-lain yang sudah disebutkan yang hasilnya dipaparkan dalam laporan penelitian". Apabila datanya terkumpul, maka lalu diklasifikasikan menjadi dua kelompok data, yaitu data kuantitatif yang berbentuk angka - angka dan kualitatif yang dinyatakan dengan simbol. (Suharsimi Arikunto, 2010:282).

Populasi dalam penelitian adalah seluruh member AS Gym fitness Center berjumlah 76 member. Dalam penelitian ini sampel yang diambil dengan metode Nonprobability Sampling menggunakan Accidental sampling. Accidental sampling adalah teknik penentuan sampel berdasarkan kebetulan yaitu siapa saja member yang secara kebetulan bertemu dengan peneliti dapat digunakan sebagai sampel, bila dipandang orang yang kebetulan ditemui itu cocok sebagai sumber data 
(Sugiyono, 2017:60). Sedangkan menurut Arikunto (2013:174) sampel adalah sebagian atau wakil populasi yang diteliti. Dapat disimpulkan bahwa sampel adalah sebagian dari populasi yang mewakili karakter populasi tersebut sehingga dapat menunjang penelitian. Maka yang dimaksud accidental sampling dalam penelitian ini adalah member aktif $A S$ Gym fitness center yang sedang mengikuti latihan beban, aerobic dan yoga dan kebetulan ada atau dijumpai pada saat dilakukannya pengumpulan data yang berjumlah 37 member.

\section{Sumber Dan Teknik Pengumpulan Data}

Instrumen adalah alat atau bahan yang digunakan dalam rangka menggali dan mengukur variabel yang akan diteliti. Menurut Notoatmojo (2010) Instrumen penelitian adalah alat-alat yang akan digunakan untuk mengumpulkan data, instrumen penelitian ini dapat berupa kuesioner, formulir observasi, formulir-formulir lain yang berkaitan dengan pencatatan data dan sebagainya. Instrumen yang digunakan dalam penelitian ini menggunakan kuisioner penelitian. Kuesioner ini merupakan angket tertutup langsung dengan chek list yang berisi butir-butir pernyataan untuk diberi tanggapan oleh responden tentang persepsi member AS Gym fitness center terhadap strategi komunikasi pemasaran. Adapun kisi-kisi kuisioner dapat dilihat pada tabel di bawah ini:

TABEL KISI-KISI KUISIONER

\begin{tabular}{|c|c|c|c|c|c|}
\hline \multirow{2}{*}{ No } & \multirow{2}{*}{ Indikator } & \multirow{2}{*}{ Sub Indikator } & \multirow{2}{*}{ Butir } & \multicolumn{2}{|c|}{ Skala } \\
\hline & & & & Ya & Tdk \\
\hline \multirow{3}{*}{1} & \multirow{3}{*}{ Periklanan } & Daya tarik & 1,2 & & \\
\hline & & Esklusifitas (berbeda) & 3,4 & & \\
\hline & & $\begin{array}{l}\text { Kepercayaan } \\
\text { Konsumen }\end{array}$ & 5,6 & & \\
\hline \multirow{3}{*}{2} & \multirow{3}{*}{ Personal Selling } & Komunikasi personal & 7,8 & & \\
\hline & & Penampilan & $9,10,11$ & & \\
\hline & & Kelengkapan prospek & 12,13 & & \\
\hline \multirow{3}{*}{3} & \multirow{3}{*}{$\begin{array}{l}\text { Promosi } \\
\text { Penjualan }\end{array}$} & Manfaat produk & $14,15,16$ & & \\
\hline & & Infromasi perusahaan & 17,18 & & \\
\hline & & Tujuan perusahaan & 19,20 & & \\
\hline
\end{tabular}

\section{Keterangan skala gutment:}

Ya diberikan kode (1)

Tdk diberikan kode $(0)$

\section{Uji Coba Instrumen}

a. Uji Validasi dan Reliabilitas Angket/Kuisioner

Melakukan validasi pada kuisioner penelitian, dibutuhkan langkah-langka sebagai berikut:

1. Menentukan validator

Validator dalam penelitian ini adalah validator ahli Ekonomi Manajemen.

2. Menghitung dan menganalisis angka validasi pertanyaan

Sujarweni (2014:192) uji validasi/validitas digunakan untuk mengetahui kelayakan butir-butir pertanyaan dalam mendefinisikan suatu variabel. Daftar pertanyaan ini pada umumnya mendukung suatu kelompok variabel tertentu. Uji validitas pada penelitian ini akan dilakukan dengan menguji kelayakan setiap 
butir pertanyaan. Hasil $r$ hitung dibandingkan degan hasil $r$ table dimana $\mathrm{df}=\mathrm{n}-2$ dengan taraf signifikan 5\%. Jika $r$ table $<r$ hitung maka valid. Berikut dibawah ini rumus uji validitas dengan menghitung nilai korelasi masing-masing pertanyaan.

Keterangan :

$$
r=\frac{N\left(\sum X Y\right)-\left(\sum X \sum Y\right)}{\sqrt{\left.\left[N \sum X^{2}-\left(\sum X\right)^{2}\right)\right]\left[N \sum Y^{2}-\left(\sum Y\right) 2\right]}}
$$

$\mathrm{R}=$ Nilai Korelasi Pertanyaan

$\mathrm{N}=$ Jumlah Sampel

$\mathrm{X}=$ Skor pertanyaan nomor 1

$Y=$ Skor total seluruh pertanyaan

$\mathrm{XY}=$ Skor pertanyaan nomor 1 dikalikan dengan skor total.

Hasil uji validitas untuk berapa besar persepsi member AS Gym fitness center terhadap strategi komunikasi pemasaran sebanyak 20 item tersebut semuanya dinyatakan valid. Hasil uji validitas dari 20 butir sebagai berikut pengujian validitas didasarkan pada jika $r_{\text {hitung }}>r_{\text {tabel. }}$. Penentuan $r_{\text {tabel }}$ didapat dari taraf signifikasi $0,05 \%$ dengan $\mathrm{DF}=\mathrm{N}-1(20-1)$ yaitu 19. Maka rtabel diperoleh 0,433.

\section{b. Uji Reabilitas}

Uji realibilitas adalah untuk mengetahui konsisten alat ukur, apakah alat pengukur yang digunakan dapat diandalkan dan tetap konsisten jika pengukuran tersebut diulang. Untuk uji realibilitas menggunakan rumus Alpha Cronbach,

$$
r_{11}=\left(\frac{k}{k-1}\right)\left(1-\frac{\sum \sigma_{b}^{2}}{\sigma_{t}^{2}}\right)
$$

Keterangan :

r11 =koefisien reliabilitas alpha

$\mathrm{k}=$ jumlah item pertanyaan

$\sum \mathrm{b} 2 \sigma=$ jumlah varian butir

$\sigma^{2} \mathrm{t} \quad=$ varians total.

(Sumber : Arikunto, 2010 : 112)

Kriteria instrument dikatakan handal (reliable) bila memiliki koefisien keandalan atau alpha sebesar 0,6 atau lebih. Dapat dilihat pada tabel berikut :

TABEL KRITERIA RELIABILITAS INSTRUMEN

\begin{tabular}{|c|c|}
\hline Interval Koefisien & Kriteria Keterandalan \\
\hline $0.80-1.000$ & Sangat Tinggi \\
\hline $0.60-0.799$ & Tinggi \\
\hline $0.40-0.599$ & Cukup \\
\hline $0.20-0.399$ & Rendah \\
\hline $0.00-0.199$ & Sangat Rendah \\
\hline
\end{tabular}

Untuk mempermudah penelitian, peneliti menggunakan alat bantu SPSS 20 for windows. Berikut merupakan hasil uji realibilitas atas 20 pernyataan yang telah diuji validatasnya dapat dilihat pada tabel berikut ini : 


\section{TABEL HASIL UJI RELIABILITAS DATA \\ Case Processing Summary}

\begin{tabular}{|c|r|r|}
\hline & N & \multicolumn{1}{|c|}{$\%$} \\
\hline Cases Valid & 20 & 100.0 \\
Excluded & \\
Total & 0 & .0 \\
& 20 & 100.0 \\
\hline
\end{tabular}

Reliability Statistics

\begin{tabular}{|l|l|}
\hline Cronbach's Alpha $^{\mathrm{a}}$ & N of Items \\
\hline .607 & 20 \\
\hline
\end{tabular}

Dari hasil diatas menunjukkan bahwa reliabilitas atas pernyataan yang telah diuji validitasnya tergolong pada kriteria tinggi dan $r$ hitung $(0,607)$ lebih besar dari $r$ tabel $(0,433)$ sehingga peneliti menyimpulkan bahwa pernyataan yang ada mempunyai ukuran konstan dan dapat dipercaya karena berada di kriteria tinggi.

\section{Teknik dan Analisis Data}

Teknik analisa data merupakan suatu teknik untuk memperoleh kesimpulan atas masalah yang sedang diteliti, maka teknik analisa merupakan suatu hal yang saapngat penting dalam sebuah penelitian. Adapun analisis data yang digunakan pada penelitian ini adalah menghitung persentase persepsi member AS Gym Fitness Center terhadap Strategi Komunikasi Pemasaran. Adapun langkah-langkah dari metode ini ialah sebagai berikut :

1. Membuat tabel jawaban angket

2. Menentukan skor jawaban responden dengan ketentuan skor yang telah ditetapkan.

3. Menjumlah skor jawaban yang diperoleh dari tiap-tiap responden.

4. Memasukan skor tersebut ke dalam rumus dengan rumus analisis persentase sebagai berikut :

Keterangan :

$$
\mathrm{P}=\frac{F}{N} \times 100
$$

$\mathrm{P} \quad$ : Persentase nilai

$\mathrm{F} \quad$ : Frekuensi nilai yang diperoleh

$\mathrm{N} \quad$ : Jumlah seluruh anggota

Untuk mempermudah dalam proses perhitungan dan pengolahan data maka, dalam penelitian ini menggunakan software SPSS (Statistical Program and Service Solution) Version 20.0 for Windows

\section{HASIL PENELITIAN DAN PEMBAHASAN Deskripsi Pelaksanaan Penelitian}

Penelitian dengan judul komunikasi pemasaran pada pusat kebugaran (fitness center) AS GYM Kota Palembang dilaksanakan di lokasi latihan (fitness center) AS GYM yang berdomisili di di Jalan Kebun Bunga No 1466 B-D, Kebun Bunga, Kec. Sukarami, Kota Palembang, Sumatera Selatan 30153. Pelaksanaan peneltian ini 
dilangsungkan pada hari Kamis tanggal 5 November tahun 2020 dengan melibatkan sebanyak 17 atlet dan member pada pusat kebugaran tersebut. Proses penelitian dilaksanakan dengan panduan protokol kesehatan ketat. Pengumpulan data dilakukan dengan penyebaran kuisioner. Tidak ada hambatan selama proses penelitian berlangsung, mengingat prosedur penelitian dijelaskan dengan rinci pada seluruh aspek terkait.

\section{Deskripsi Data Penelitian}

As Gym merupakan pusat kebugaran atau fitness center yang berdomisili di Jalan Kebun Bunga No 1466 B-D, Kebun Bunga, Kec. Sukarami, Kota Palembang, Sumatera Selatan 30153. . As Gym berdiri pada tanggal 28 September 2015 oleh pengusaha bernama Lia Wahyuni . As Gym telah beroperasi selama lebih kurang 5 tahun dalam membina kebugaran masyarakat Kota Palembang. Pusat kebugaran ini memiliki fasilitas yang lengkap untuk seluruh kegiatan weight training, aerobic dan yoga.

Pada tabel di bawah ini akan dipaparkan deskripsi pengunjung atau member sebagai berikut:

Tabel Member Berdasarkan Tahun

\begin{tabular}{|c|c|c|c|c|}
\hline \multirow{2}{*}{ No } & \multirow{2}{*}{ Tahun } & \multicolumn{2}{|c|}{ Jenis Kelamin } & \multirow{2}{*}{ Jumlah } \\
\hline & & Lk & $\mathrm{Pr}$ & \\
\hline 1 & 2015 & 43 & 18 & 61 \\
\hline 2 & 2016 & 68 & 16 & 84 \\
\hline 3 & 2017 & 46 & 12 & 58 \\
\hline 4 & 2018 & 44 & 21 & 65 \\
\hline 5 & 2019 & 39 & 13 & 52 \\
\hline 10 & 2020 & 64 & 12 & 76 \\
\hline
\end{tabular}

Berdasarkan tabel di atas diperoleh informasi bahwa tahun 2016 merupakan puncak pencapaian tertinggi dari jumlah member yang latihan pada As Gym fitness center Palembang dengan jumlah member 84 orang dengan rincian 68 orang lakilaki dan 16 orang perempuan, dan terendah pada tahun 2019 yaitu 52 orang member dengan rincian 39 orang laki-laki dan 13 orang perempuan. ini :

Data pada tabel di atas, selanjutnya akan dipaparkan dalam diagram di bawah

\section{Gambar Diagram Member As Gym}

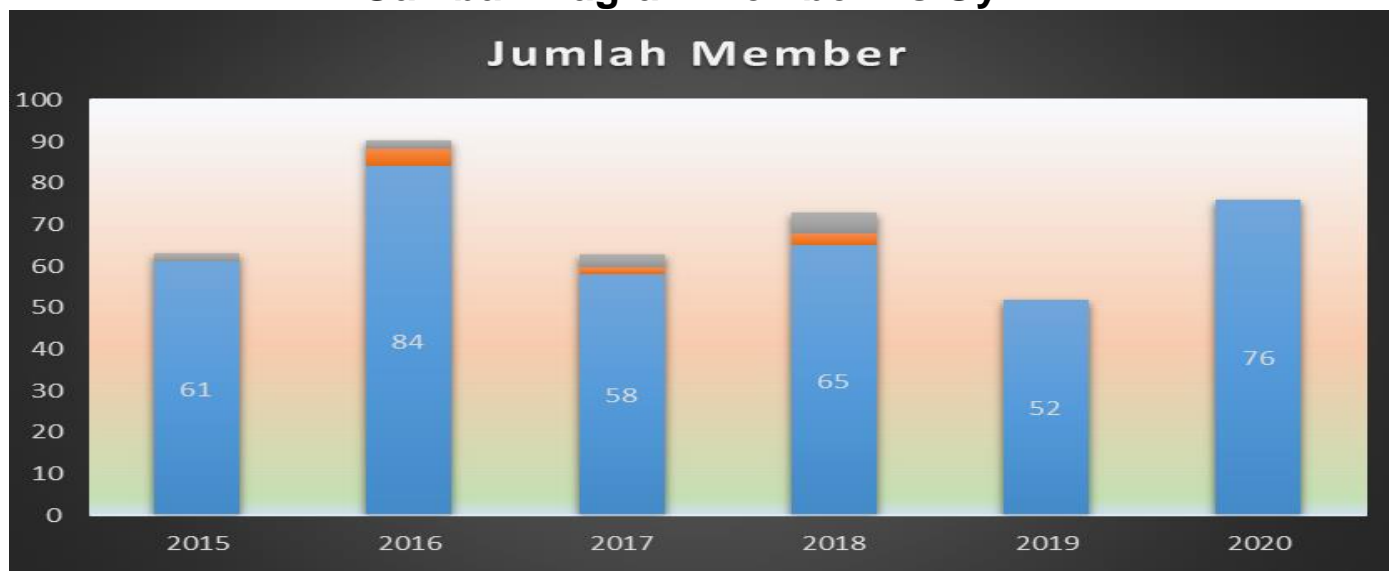

(Sumber : Dokumen Peneliti) 
Berdasarkan tabel di atas diperoleh informasi bahwa tahun 2016 merupakan puncak pencapaian tertinggi dari jumlah member yang latihan pada As Gym Palembang dengan 68 orang laki-laki dan 16 orang perempuan, dan terendah pada tahun 2019 yaitu 52 orang member dengan rincian 39 orang laki-laki dan 13 orang perempuan.

\section{Persentase Persepsi Member Berdasarkan Indikator}

Untuk menentukan persentase persepsi member AS Gym Fitness Center dalam memilih tempat kebugaran ditinjau berdasarkan masing-masing aspek diperlukan rumus sebagai berikut:

$$
P=\frac{\text { Skor Perolehan Seluruh Jawaban }(F)}{\text { Skor Maksimal Seluruh Jawaban Aspek }(N)} \times 100
$$

\section{Persentase Persepsi Member Berdasarkan Periklanan / Advertising}

Persepsi member dalam memilih AS Gym Fitness Center Berdasarkan periklanan/advertising yang meliputi indikator daya Tarik, ekslusifitas (berbeda) dan kepercayaan konsumen. Periklanan yang dilakukan tim marketing yaitu membuat akun medsos yang isi nya memberi informasi program latihan, fasilitas, suplemen pendukung dan jadwal latihan AS Gym Fitness Center. Hasil penelitian berdasarkan angket sebanyak 30\% persentase persepsi member memilih AS Gym berdasarkan periklanan / advertising. Hasil tersebut diperoleh berdasarkan rumus di bawah ini :

Diketahui,

Frekuensi jumlah jawaban responden aspek periklanan $(F)=165$

Total jawaban maksimal seluruh responden $(N)=550$

$$
P=\frac{(F)}{(N)} \times 100=\frac{165}{550} \times 100=30 \%
$$

\section{Persentase Persepsi Member Berdasarkan Personal Selling}

Persepsi member dalam memilih AS Gym Fitness Center Berdasarkan Personal Selling atau penjualan tatap muka dengan indikator komunikasi personal, penampilan dan kelengkapan prospek. Dalam hal ini peneliti melihat personal selling yang dilakukan marketing ataupun pengelola AS Gym yaitu mengajak rekan, saudara atau orang yang baru kenal untuk bergabung di AS Gym dengan menawarkan fasilitas terbaik yang dimiliki AS Gym. Hasil penelitian persentase persepsi member berdasarkan personal selling sebanyak 36\%. Hasil tersebut diperoleh berdasarkan rumus di bawah ini :

Diketahui,

Frekuensi jumlah jawaban responden aspek periklanan $(F)=196$

Total jawaban maksimal seluruh responden $(\mathrm{N})=550$

$$
P=\frac{(F)}{(N)} \times 100=\frac{196}{550} \times 100=36 \%
$$

\section{Persentase Persepsi Member Berdasarkan Promosi Penjualan/sales Promotion.}

Persepsi member berdasarkan Promosi penjualan, indikator nya meliputi manfaat produk, informasi perusahaan dan tujuan perusahaan. Strategi yang dilakukan pengelola AS Gym yaitu memberi informasi di media sosial contoh nya Instagram mengenai profil AS gym, produk suplemen yang dijual sebagai pendukung 
nutrisi member dan event-event yang diikuti member AS Gym. Dalam hal ini persentase persepsi member berdasarkan promosi penjulan yang di dapat dari hasil angket sebanyak 34\%. Hasil tersebut diperoleh berdasarkan rumus di bawah ini :

Diketahui,

Frekuensi jumlah jawaban responden aspek periklanan $(\mathrm{F})=189$

Total jawaban maksimal seluruh responden $(\mathrm{N})=550$

$$
P=\frac{(F)}{(N)} \times 100=\frac{189}{550} \times 100=34 \%
$$

\section{Analisis Data Penelitian}

Penelitian dengan tujuan untuk mengetahui Persepsi member terhadap strategi komunikasi pemasaran yang dilakukan fitness center AS Gym Kota Palembang ditinjau berdasarkan persepktif responden dapat dilihat pada tabel di bawah ini:

\begin{tabular}{|c|c|}
\hline \multicolumn{2}{|c|}{ TABEL PERPEKTIF RESPONDE } \\
\hline ASPEK & PERSENTASE \\
\hline Periklanan & 30 \\
\hline Personal Selling & 36 \\
\hline Promosi Penjualan & 34 \\
\hline
\end{tabular}

(Sumber : Dokumentasi Peneliti, 2020) bawah ini:

Selanjutnya tabel di atas akan dipaparkan dalam bentuk diagram lingkaran di

Gambar Diagram Perspektif Responden

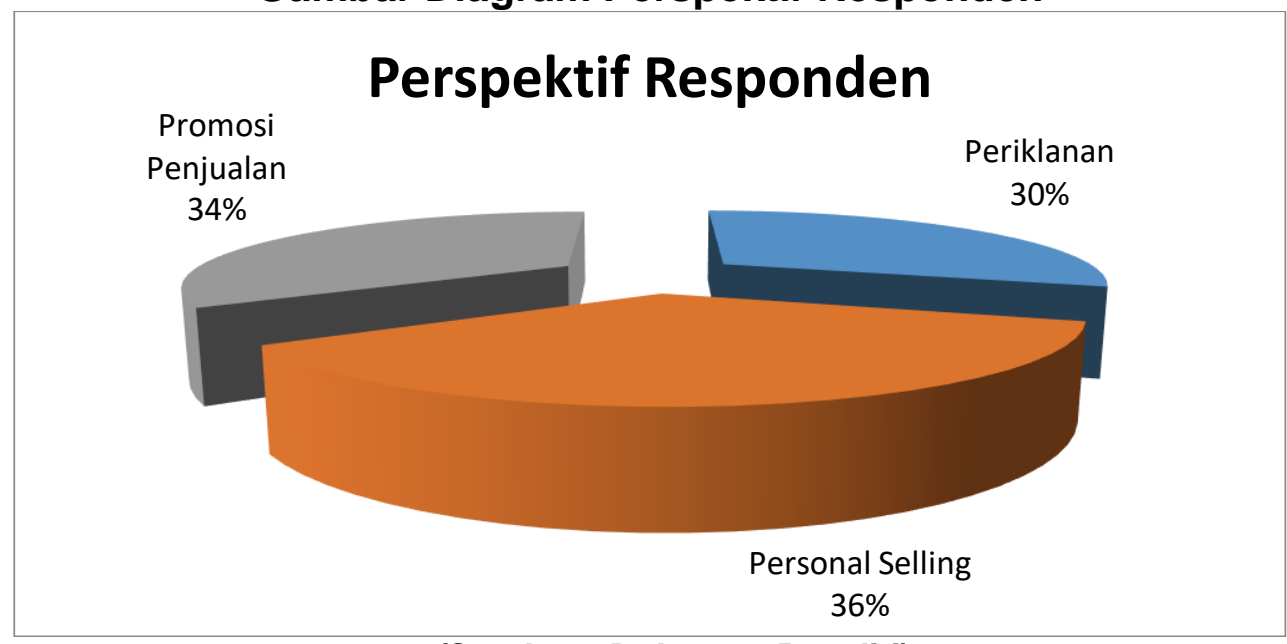

(Sumber : Dokumen Peneliti)

Dari tabel dan diagram di atas, dapat dipaparkan bahwa komunikasi pemasaran yang dilakukan oleh pengusaha AS Gym Palembang ditinjau dari aspek periklanan adalah 30\% disukai member, dari aspek personal selling adalah $36 \%$ disukai member dan dari aspek promosi penjualan sebesar 34\% disukai member.

Berdasarkan temuan hasil penelitian dan analisis data penelitian, penelitian ini memberikan hasil bahwa strategi komunikasi pemasaran yang dilakukan oleh pengusaha AS Gym Palembang ditinjau dari aspek periklanan adalah 30\% disukai member, dari aspek personal selling adalah $36 \%$ disukai member dan dari aspek promosi penjualan sebesar 34\% disukai member. 
Hasil penelitian di atas, bahwa strategi komunikasi pemasaran yang dilakukan oleh pihak manajemen As Gym terhadap member yang bergabung dalam pusat kebugaran tersebut dikarenakan aspek periklanan, aspek personal selling dan promosi penjualan. Dari ketiga aspek di atas, bahwa member tertarik untuk bergabung latihan pada pusat kebugaran AS Gym karena dipengaruhi paling besar oleh personal selling yang dilakukan oleh tim marketing As Gym, artinya tim marketing AS Gym dalam hal melakukan penjualan memiliki tingkat komunikasi secara personal yang mampu meyakinkan konsumen atau member sehingga mengambil keputusan untuk bergabung pada pusat kebugaran tersebut.

\section{E. KESIMPULAN DAN SARAN}

1) Kesimpulan

Berdasarkan analisis data dan temuan hasil penelitian, penelitian dapat diambil kesimpulan bahwa bahwa komunikasi pemasaran yang dilakukan oleh pengusaha AS Gym Palembang ditinjau dari aspek periklanan adalah 30\% disukai member, dari aspek personal selling adalah $36 \%$ disukai member dan dari aspek promosi penjualan sebesar 34\% disukai member.

2) Saran

Berdasarkan temuan hasil penelitian di atas, hal-hal yang disarankan dalam penelitia ini adalah:

a. Agar Tim Marketing semakin meningkatkan pola strategi komunikasi pemasaran, sehingga jumlah member semakin bertambah.

b. Agar As Gym semakin meningkatkan fasilitas latihan sehingga menambah semangat member dalam latihan kebugaran.

\section{DAFTAR PUSTAKA}

Arikunto, S. (2010). Prosedur Penelitian Suatu Pendekatan Praktik. Jakarta: Rineka Cipta.

Arikunto, S. (2013). Prosedur Penelitian: Suatu Pendekatan Praktik. Jakarta: Rineka Cipta.

Colledge, F., Cody, R., Pühse, U., \& Gerber, M. (2020). Responses of fitness center employees to cases of suspected eating disorders or excessive exercise. Journal of Eating Disorders, 8(1).https://doi.org/10.1186/s40337-020$\underline{0284-9}$

Fadila, Dewi dan Lestari, Sari. (2013). Perilaku Konsumen. Palembang: Citra Books Indonesia.

Giriwijoyo, Santosa. (2004). IImu Faal Olahraga. Bandung : FPOK - UPI.

Gronroos, C., (2000). Service Management and Marketing: A Customer Relationship Management Approach, 2nd ed. West Sussex: Chichester

Notoatmodjo, S. (2010). Metodologi Penelitian Kesehatan. Jakarta : Rineka Cipta.

Nursan, (2019) Analisis Manajemen Usaha Fitness Centre Terhadap Peningkatan Minat Pada Fitness Bagi Masyarakat di Kota Makassar. S1 thesis, Pascasarjana. URI : http://eprints.unm.ac.id/id/eprint/12696 
Persepsi (Def.2)(n.d). Dalam Kamus Besar Bahasa Indonesia (KBBI) Online. Diakses melalui https://kbbi.web.id/persepsi, 26 Oktober 2020.

Purba, Amir, dkk. (2006). Pengantar Ilmu Komunikasi. Medan: Pustaka Bangsa Press.

Reftari, D. H., Suryana, A., \& Setiaman, A. (2018). Komunikasi Pemasaran Olahraga Renang. Jurnal Kajian 247.https://doi.org/10.24198/jkk.v6i2.13221

Komunikasi, 6(2),

Sujarweni, V. Wiratna. (2014). Metode Penelitian: Lengkap, Praktis, dan Mudah Dipahami.Yogyakarta: Pustaka Baru Press.

Sukarmin, Y. (2014). Pemasaran Olahraga Melalui Berbagai Event Olahraga. Jurnal Pendidikan kesehatan dan rekreasi. Artikel Universitas Negeri Yogyakarta.

Sutisna, (2012), Perilaku Konsumen dan Komunikasi Pemasaran, Edisi Kedua, Bandung: Remaja Rosdakarya.

Sugiyono. (2017). Metode Penelitian Kombinasi (mixed methods). Bandung: Alfabeta.

Undang - Undang Republik Indonesia No 3 (2005). Sistem Keolahragaan Nasional. Jakarta

Undang - Undang Republik Indonesia No 3 (2005). Sistem Keolahragaan Nasional. Jakarta

Wongkitogalo.id.blogspot.com.(2019, 21 April). Daftar Tempat Fitness Di Palembang Beserta Alamatnya. Diakses 26 Oktober 2020, Dari https://wong-kito-galoid.blogspot.com/2018/04/daftar-tempat-fitnes-di-palembang.html 